Prepared for the U.S. Department of Energy

under Contract DE-AC05-76RL01830

\title{
Funding Formulas and Arrangements under IEA Implementing Agreements
}

A Delgado M Evans

December 2008

Pacific Northwest

NATIONAL LABORATORY

Proudly Operated by Battelle Since 1965 


\title{
DISCLAIMER
}

This report was prepared as an account of work sponsored by an agency of the United States Government. Neither the United States Government nor any agency thereof, nor Battelle Memorial Institute, nor any of their employees, makes any warranty, express or implied, or assumes any legal liability or responsibility for the accuracy, completeness, or usefulness of any information, apparatus, product, or process disclosed, or represents that its use would not infringe privately owned rights. Reference herein to any specific commercial product, process, or service by trade name, trademark, manufacturer, or otherwise does not necessarily constitute or imply its endorsement, recommendation, or favoring by the United States Government or any agency thereof, or Battelle Memorial Institute. The views and opinions of authors expressed herein do not necessarily state or reflect those of the United States Government or any agency thereof.

\author{
PACIFIC NORTHWEST NATIONAL LABORATORY \\ operated by \\ BATTELLE \\ for the \\ UNITED STATES DEPARTMENT OF ENERGY \\ under Contract DE-AC05-76RL01830
}

Printed in the United States of America
Available to DOE and DOE contractors from the Office of Scientific and Technical Information,
P.O. Box 62, Oak Ridge, TN 37831-0062;
ph: (865) 576-8401
fax: $(865)$ 576-5728
email: reports@adonis.osti.gov

\begin{abstract}
Available to the public from the National Technical Information Service, U.S. Department of Commerce, 5285 Port Royal Rd., Springfield, VA 22161 ph: (800) 553-6847 fax: $(703) 605-6900$ email: orders@ntis.fedworld.gov online ordering: http://www.ntis.gov/ordering.htm
\end{abstract}

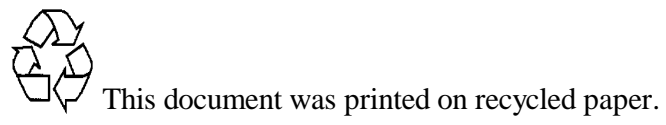




\title{
Funding Formulas and
} Arrangements under IEA Implementing Agreements

\author{
A Delgado \\ M Evans
}

December 2008

Prepared for the U.S. Department of Energy

under Contract DE-AC05-76RL01830

Pacific Northwest National Laboratory

Richland, Washington 99352 
Date: $\quad$ December 21, 2008

To: Jerry Dion

From: $\quad$ Meredydd Evans

Subject: Arrangements under IEA Implementing Agreements

The Pacific Northwest National Laboratory ${ }^{1}$ has researched how participating countries divide funding obligations under International Energy Agency (IEA) Implementing Agreements (IAs). This is part of a broader assessment evaluating the buildings-area IAs. This particular part of the analysis looked at 12 IAs funded by the U.S. Department of Energy. By selecting a range of agreements, we hoped to understand both the structure of typical arrangements and the range of funding formulas. PNNL asked the U.S. Executive Committee (ExCo) members how the total contribution for their IA and its Annexes were determined, and how the total was then divided between participating countries. The stakeholders of the following IAs were interviewed:

1. Advanced Fuel Cells

2. Climate Technology Initiative

3. Demand-Side Management

4. District Heating and Cooling and CHP

5. Energy Conservation in Building and Community System

6. Energy Efficient Electrical Equipment

7. Energy Technology Data Exchange

8. Heat Pump

9. High-Temperature Super Conductivity (HTS) on the Electric Power Sector

10. Hybrid and Electrical Vehicles

11. Industrial Energy-Related Technologies and Systems (IETS)

12. Solar Heating and Cooling.

\section{Overview of Funding Arrangements for IEA Implementing Agreements}

The table below summarizes the general types of funding arrangements we found. Funding arrangements often vary for central fund of an IA and the annexes within the IA.

\footnotetext{
${ }^{1}$ Alison Delgado prepared the analysis for this memo.
} 


\begin{tabular}{|l|l|l|}
\hline \multicolumn{1}{|c|}{ Funding Arrangements } & \multicolumn{1}{|c|}{ IA's Central Fund } & \multicolumn{1}{c|}{ Annexes } \\
\hline $\begin{array}{l}\text { Monetary contributions } \\
\text { are fixed }\end{array}$ & Every participating country pays the same fee \\
\hline $\begin{array}{l}\text { Monetary contributions } \\
\text { based on size of country }\end{array}$ & $\begin{array}{l}\text { 1) According to GDP plus base fee or multiplier, or } \\
\text { 2) Countries assigned to contribution levels based on size of country }\end{array}$ \\
\hline Task-sharing & \multicolumn{2}{|l|}{$\begin{array}{l}\text { Participant performs and/or offers expertise } \\
\text { on project. Funding is provided by } \\
\text { participant as in-kind and/or acquired from } \\
\text { government funding agencies or private } \\
\text { sources to support expert participation. }\end{array}$} \\
\hline
\end{tabular}

\section{Implementing Agreement Central Fund}

All ExCo members mentioned the IA having a Secretariat Fund or a similar central fund. The central fund is made available to the ExCo by each participating country to cover general administrative costs. For example, in the case of the Advanced Fuel Cells IA, uses of the common fund include arranging meetings, writing minutes, reporting to the IEA, producing publications, and developing the IA website. There are three general methods practiced by IAs for dividing the contributions between countries: (1) equal shares, (2) formula-based contributions (generally based on the size of the country ${ }^{2}$ ), and (3) a combination of the last two whereby countries are grouped into fixed contribution levels (also based on country size).

Equal shares Participating countries of the following IAs make equal contributions (In USD):

- For Advanced Fuel Cells, Demand-Side Management $(\$ 3,359)$

- Solar Heating and Cooling $(\$ 8,000)$

- Hybrid and Electrical Vehicles $(\$ 8,000)$

- Climate Technology Initiative $(\$ 12,560)$

- Energy Efficient Electrical Equipment $(\$ 13,221)$

- Energy Technology Data Exchange $(\$ 15,000)$

Formula-based contributions For other implementing agreements, the size of a country is mainly determined by the country's Gross Domestic Product (GDP), in addition to a base fee or multiplier. For example, the Energy Conservation in Building and Community System IA uses a base multiplier, which is then used against the GDP of each country. Accordingly, the US, Japan and the UK, pay the highest fees, followed by Canada, France and Italy. For the HighTemperature Super Conductivity IA, a consensus on the budget is first reached. Each participating country then contributes a nominal amount of $\$ 5,000$, and the remaining funds needed to reach the desired budget are subsequently divided according to the OECD/IEA dues structure. In this way, large countries pay more than smaller countries.

\footnotetext{
${ }^{2}$ Currently, size of country is determined from the country's Gross Domestic Product (GDP) and, in some cases, also from the country's energy consumption volumes.
} 
Fixed contribution levels Other IA Executive Committees assign contribution levels. For the Heat Pump IA, there are three contribution levels based roughly on the size of the country: 40,000 Euros (US, Japan, and Sweden), 15,000 Euros (Canada, Germany, France, Italy and Korea) and 10,000 Euros (Switzerland, Austria, Netherlands, and Norway), respectively. Typically, however, the host country contributes a greater amount to the central fund. Similarly, the Industrial Energy-Related Technologies and Systems IA sets two contribution levels based mainly on GDP: $\$ 7,000$ for large countries (e.g., US), and about $\$ 3,500$, or half, for smaller countries (e.g., Mexico, Portugal and Brazil).

\section{Contributions at the Annex-level}

The ways in which contribution structures work at the Annex-level are less defined. In the case of the Heat Pump and Energy Technology Data Exchange Agreements, the fees structure is decided by participants at the Annex-level, and the contributions made vary from Annex to Annex. However, IEA IA country contributions generally fall under three contribution structures: (1) paying a fixed monetary fee, (2) paying a fee based on the size of the country, or (3) via task-sharing. Task sharing occurs when each Participant performs and finances the project (in-kind). In the case of task sharing, it is not uncommon for participating countries to find resources from government funding agencies, or private sources to support expert participation.

It is worth noting that the Energy Technology Data Exchange IA has no Annexes, but instead has one central Agreement, whereby countries participate by paying a fixed monetary contribution of $\$ 15,000$, as mentioned above, in addition to paying an additional contribution based loosely on RD\&D budgets and according to country size (Figure 1). More and more, smaller countries are contributing information and/or participating in database responsibilities (task sharing).

Figure 1: 2006 RD\&D Budgets (In Million USD)

\begin{tabular}{|l|l|l|l|}
\cline { 2 - 4 } \multicolumn{1}{c|}{} & Energy Efficiency & $\begin{array}{l}\text { Of which: Residential \& } \\
\text { Commercial Buildings }\end{array}$ & Total Energy RD\&D \\
\hline Japan & 448.849 & 165.885 & $3,620.412$ \\
\hline United States & 352.077 & 56.855 & $3,200.358$ \\
\hline Germany & 21.066 & 12.964 & 534.812 \\
\hline Switzerland & 17.558 & 6.385 & 131.684 \\
\hline Denmark & 9.576 & 4.750 & 101.724 \\
\hline Sweden & 28.555 & 4.341 & 93.313 \\
\hline $\begin{array}{l}\text { Estimated IEA Total } \\
\text { from 27 countries) }\end{array}$ & $1,286.000$ &.. & $10,945.000$ \\
\hline
\end{tabular}

Source: R\&D Statistics (OECD/IEA, 2007)

Providing Operating Agents (OA) is another common in-kind contribution practiced by participating countries. For example, the US provides an Operating Agent for one of Advanced Fuel Cells IA's Annexes, with other countries extending OAs for their other five Annexes. 


\section{Case Study: Annex Funding Contributions for the District Heating and Cooling and CHP (Combined Heat and Power) IA}

As of May 16, 2008, and for the period 2008 to 2011, the District Heating and Cooling and CHP (DHC-CHP) IA adheres to a set of IEA Contributions Objectives for each of its Annexes. For each Annex, the participants pay an annual contribution based on the Principles of Contributions. The Principles of Contributions are based on two parameters: (1) the participating countries' economic situation, and (2) the market share for district heating in the countries. For an Annex, each Participant is invited to submit proposals, and the projects carried out by the Contracting Parties within the Framework of the IA are decided by the ExCo in consensus. A Contracting Party includes a government of IEA ("Agency") countries, governments of other countries invited by the Governing Board of the Agency of Contracting Parties, international organizations or parties designated by their respective governments.

A base contribution (B) is determined from the country's Gross Domestic Product (GDP) as follows:

\begin{tabular}{|l|l|}
\hline GDP & $\begin{array}{l}\text { Base } \\
\text { contribution }(\mathrm{B})\end{array}$ \\
\hline$($ MUSD) & (USD/year) \\
\hline$<100,000$ & 10,000 \\
\hline $100,001<250,000$ & 20,000 \\
\hline $251,001<500,000$ & 30,000 \\
\hline $500,001<750,000$ & 40,000 \\
\hline $750,001<2,000,000$ & 50,000 \\
\hline $2,000,001<10,000,000$ & 80,000 \\
\hline$>10,000,001$ & 120,000 \\
\hline
\end{tabular}

If the market share for district heating is low in a given country, a reduction factor $(\mathrm{M})$ is calculated, and the total contribution is then $\mathrm{C}=\mathrm{B}^{*} \mathrm{M}$. Based on the District Heating market share, the reduction factor $(\mathrm{M})$ on the contributions is applied as follows:

\begin{tabular}{|l|l|}
\hline $\begin{array}{l}\text { Market share of District } \\
\text { Heating }(\%)\end{array}$ & $\begin{array}{l}\text { Market share reduction factor } \\
(\mathrm{M})\end{array}$ \\
\hline $0<15$ & 0.8 \\
\hline $15.1<33.2$ & 0.9 \\
\hline$>33.3$ & 1.0 \\
\hline
\end{tabular}

In the hopes of attracting more country participation, 'discounted contributions' are also offered. Discounted contributions are reserved for smaller countries only — with less than one million inhabitants, or countries with a GDP less than 100,000 MUSD.

Limitations for each Annex contribution are also set. Specifically, (a) no country can pay more than $25 \%$ of the total contribution, or a maximum $\$ 80,000$ per annum, (b) the minimum contribution for a Contracting Party is $\$ 20,000$ annual, and (c) the minimum discounted contribution for a Contracting Party is $\$ 10,000$ annual. 